Dhaka Univ. J. Biol. Sci. 31(1): 193-201, 2022 (January) ～DOI: https://doi.org/10.3329/dujbs.v31i1.57928

\title{
OPTIMIZATION OF CULTURE MEDIA INGREDIENT AND INOCULUM ON THE YIELD OF TUBIFEX WORMS AT PILOT SCALE LEVEL
}

\author{
Md Inja-Mamun Haque* and Mahmud Hasan \\ Department of Fisheries, University of Dhaka, Dhaka-1000, Bangladesh \\ Keywords: Culture media, Tubifex, Mustard oil cake
}

\begin{abstract}
While the first experiment evaluated the effect of media ingredient mustard oil cake wetted in cattle blood, rice gruel and subsurface clean water, the second experiment focused on the effects of two doses of media levels 75 and $100 \mathrm{mg}$ $\mathrm{cm}^{-2}$ and two levels of inoculums 75 and $100 \mathrm{mg} \mathrm{cm}^{-2}$, on the yield of tubifex worms. Wet medium did not have significant effect on the yield of tubifex worms harvested after 70-day culture duration. Applying $75 \mathrm{mg} \mathrm{cm}^{-2}$ mustard oil cake as media ingredient resulted in the significantly higher $(\mathrm{p}<0.05)$ yield than that of $100 \mathrm{mg} \mathrm{cm}^{-2}$. On the contrary, worms' inoculum at the rate of $100 \mathrm{mg} \mathrm{cm}^{-2}$ gave significantly higher yield than did the $75 \mathrm{mg} \mathrm{cm}^{-2}$ inoculum. The results of this study have demonstrated that mustard oil can be used as the only culture media ingredient and the combination of $75 \mathrm{mg} \mathrm{cm}^{-2}$ media ingredient and 100 $\mathrm{mg} \mathrm{cm}^{-2}$ worm's inoculum is the best combination at pilot scale level culture of tubifex.
\end{abstract}

\section{Introduction}

Tubifex worms, commonly known as sludge worms, are reddish in color usually found in lakes, sewage canals, drains or ponds enriched with organic detritus with steady or continuous water flow ${ }^{(1)}$. These tiny cosmopolitan freshwater oligochaetes are bilaterally symmetrical with tapering ends(2). The frontal portion of the body settles in the mud or silt while the rest of the body waves vigorously above the ground in a breathing movement to increase aeration ${ }^{(3)}$. However, Mariom et al.(4) identified three (Tubifex, Limnodrilus, and Aulodrilus) genus of the family Tubificidae whereas Haque et al.(5) reported two species (Limnodrilus hoffmeisteri and Limnodrilus claparedianus-cervix) of 'tubifex worms' under the Limnodrilus genera. The high food value $\left(5,575 \mathrm{cal} \cdot \mathrm{g}^{-1}\right.$ on a dry weight basis) of tubifex place them superior quality cheapest live food in intensive aquaculture, particularly for catfishes, climbing perch and murrel, of Bangladesh(6).

Culture of high value catfishes such as stinging catfish Heteropneustes fossilis (Bloch 1794) and pabda Ompokspp. is increasingly becoming popular because of their high market demand and profit. Additionally, the rearing of walking catfish, Clarias batrachus

*Author for correspondence: <injamamunhaque@du.ac.bd>. 
(Linnaeus 1758), climbing perch Anabas testudineus (Bloch 1792), and murrel Channa striata (Bloch 1793) is also a profitable enterprise in the rural Bangladesh. Although farming of striped catfish Pangasianodon hypophthalmus (Sauvage 1878) has been dropped drastically due to low market price and high feed cost, it contributes nearly $11 \%$ of the total fish production of Bangladesh ${ }^{(7)}$. The commercial culture of these fishes require best quality live food for proper growth and development. The blended tubificid worms are fed by spawn whereas the fry and other advantage stages prefer the whole worms ${ }^{(8)}$. Alam and Mollah(9) have demonstrated that walking catfish Clarias batrachus larvae had higher survival rate and 10 times more growth over those fed with formulated dry feed.

The continuous and reliable supply of hygienically produced tubifex worms is a prerequisite to produce good quality hygienic fish seed. However, in Bangladesh, tubifex worms are drawn only from the nature which is undependable and insufficient for the rising pressure ${ }^{(10)}$. In addition, the unhealthy condition prevailing in the collection area cause the wild-caught worms hazardous which may not encounter the hygienic grade of feed for larval stages of fishes. The sustainable and reliable supply of hygienically produced tubifex worms at farm level will enhance the commercial production of catfish seeds. Besides, the chances of the outbreak of typhoid and cholera, caused by Salmonella and Vibrio spp., among the worm collectors will be minimized by commercial culture of tubifex worms ${ }^{(11)}$.

Soybean meal (SBM), mustard oil cake (MOC) and wheat bran (WB) currently are not being used for the sustainable production of tubifex worms in Bangladesh. Cow dung enhances fungal growth in the rearing unit whereas mud may provide the habitat of tubifex worms. Although wheat bran contains more than $15 \%$ high quality protein, they are covered by a matrix of cell wall polysaccharides which are not easily digested ${ }^{(12)}$. Soybean meal composed of $40-50 \%$ crude protein but deficient of amino acid (cystidine, methionine) and some micro nutrients (calcium, phosphorus) and vitamin B complex ${ }^{(13)}$. Mustard oil cake comprises $28-38 \%$ crude protein and all commonly found amino $\operatorname{acids}^{(14)}$.

Hossain et al.(15-16) reported that 20\% mustard oil cake (MOC), 30\% soybean meal (SBM), 20\% wheat bran (WB), 20\% cow dung (CD) and 10\% sand as the appropriate media composition for the sustainable production of tubifex in laboratory condition in which the worms inoculum was $2.5 \mathrm{mg} \mathrm{cm}^{-2}$ (for optimum harvesting experiment) and $5.0 \mathrm{mg} \mathrm{cm}^{-2}$ (for ratio optimization study). Similar observation suggested by Mariom and Mollah ${ }^{(17)}$, while developing suitable culture medium for tubificid, where the worms inoculum was $1.25 \mathrm{mg} \mathrm{cm}^{-2}$. Mollah et al.(1) found higher yield of tubifex worms by using a combination of $35 \% \mathrm{MOC}, 20 \% \mathrm{WB}, 25 \% \mathrm{CD}$ and $20 \%$ sand with worms inoculum at the rate of $1.25 \mathrm{mg} \mathrm{cm}^{-2}$. Begum et al. ${ }^{(18)}$ have demonstrated that $70 \%$ cow dung and $30 \%$ field soil is the suitable food medium for optimal growth of tubifex worms while Mandal et al.(19) used rice mill sludge, dairy sludge and raw cattle dung as culture media for 
tubifex. Hasan et al.(8) observed that the blood wetted medium produced the highest yield (worms inoculum $50 \mathrm{mg} \mathrm{cm}^{-2}$ ) in 40\% MOC, 30\% SBM and 30\% mud combination where WB was absent. However, all of these studies were carried out without giving the proper habitat of the tubificid worms. In addition, data on the optimum ratio of culture media ingredient and inoculum of tubifex worms is the lacking. Therefore, the current study is designed to optimize the effects of culture media ingredient and inoculum on the yield of tubifex worms.

\section{Materials and Methods}

Study organisms: Study animals were wild caught tubifex worms gathered from the local collectors (Jashore, Bangladesh). Upon collection clean water was used to clean the worms. Before inoculation, the worms were acclimated well by detaining in a tray with slow flow-through system over 24-hour period.

Experimental system: The experiment was conducted in a Maa Fatema Fish Hatchery, Jashore, Bangladesh. The culture systems were newly constructed twelve cemented culture raceway $(72 \times 80 \times 10 \mathrm{~cm})$ having 1-inch pond mud on the bottom. Each experimental unit received uninterrupted water supply through a 1-inch diameter porous uPVC spray bar.

Study design: While experiment 1 was a one factorial study with three replicates in which wet medium was the only experimental variable, the second experiment focused on the determination of proper dose of media application and inoculums in a $2^{2}$ factorial study. While in the first experiment wet mediums included cattle blood, rice gruel and water, the second experiment used only water. In both experiments, worms yield was the only indicator variable.

Media combination: Type and quantity of media ingredients was determined through a series of experiments ${ }^{(8)}$. Use of soybean meal (SM) was found to enhance growth of jelly like moulds which if not cleaned twice everyday covered the entire worms. Thus worms were found to die within 3-5 days. Flour used in a previous experiment was also found to remain un-decomposed even after a month. Therefore, SM and flour were not used in these two experiments. Only $50 \mathrm{mg} \mathrm{cm}^{-2} \mathrm{MOC}$ was used as media ingredient by dissolving in cattle blood, rice gruel and water in the first experiment and in water only in the second experiment.

Assemblage of culture media elements and wet media: Freshly produced MOC was collected from local market of Jashore, Bangladesh. Blood was harvested from the butchery house and rice gruel was drawn from students' dormitory (Jashore, Bangladesh). Mud was obtained from nearby pond.

Media supply: In the first experiment, each culture unit $\left(5760 \mathrm{~cm}^{2}\right)$ was given $288 \mathrm{~g}$ MOC (50 mg cm-2) upon wetting in blood and rice gruel for 7 days. Before application, 
media ingredient in each bowl was mixed well by hand twice every day. Each culture unit was filled with water until spill out before inoculation. The effect of 75 and $100 \mathrm{mg}$ $\mathrm{cm}^{-2}$ media, and 75 and $100 \mathrm{mg} \mathrm{cm}^{-2}$ worm's inoculums (with three replicates) on the yield of tubifex production was the prime target in the second experiment.

Culture technology: Culture technology was batch system in which worms were inoculated at the beginning of the study and the entire worms were harvested over a duration of 70 days.

Worms inoculation: After a day of mud application, the worms were inoculated into the culture system at a density of $50 \mathrm{mg} \mathrm{cm}^{-2}$ by following Hasan et al. ${ }^{(8)}$. Each culture unit received worms homogenously over the culture media ingredients. The second experiment determined the optimum density of media application and inoculums.

Replenishment of the culture unit: The experimental unit was renewed by 7-day wetted culture media once in every week at $50 \mathrm{mg} \mathrm{cm}^{-2}$ for the entire culture duration in the first experiment, while 2 doses of culture media $\left(75\right.$ and $100 \mathrm{mg} \mathrm{cm}^{-2}$ ) were applied in the second experiment. Before application of media water flow was stopped and restarted after 10 minutes.

Flow of water: Water flow speed was maintained to sustain the concentration of dissolved oxygen (DO) at about $4 \mathrm{mg} \mathrm{L}^{-1}$. Each experimental unit had an outlet drain.

Harvest: The yield of each culture unit was sieved for total harvest. Harvested worms were cleaned by sub-surface clean water. Blotting paper was used to clean the worms and an electronic balance (SHIMADZU, Japan) was used to weigh the worms.

Data analysis: Data were analyzed by 1-, and 2-way ANOVA by SPSS version 20.0 with the level of significance at $\mathrm{p} \varangle 0.05$. Data were presented as mean $\pm 1 \mathrm{SEM}$.

\section{Results and Discussion}

\section{Experiment 1:}

Yield of tubifex worms when blood, rice gruel and water were used as the wetting media: While the highest yield $\left(5.869 \pm 0.091 \mathrm{~kg} \mathrm{~m}^{-2}\right)$ was found in the treatment in which media ingredient was wetted in cattle blood, water wetted media treatment yielded the lowest $\left(5.562 \pm 0.099 \mathrm{~kg} \mathrm{~m}^{-2} ;\right.$ Fig. 1). However, worms found in the media ingredient wetted in rice gruel were not different from other two treatments $\left(5.6656 \pm 0.098 \mathrm{~kg} \mathrm{~m}^{-2}\right)$.

The observed no difference in yields of tubifex worms in three treatments denotes no or less effects of blood and rice gruel in enhancing yield through the absorption of protein and carbohydrate from blood and rice gruel than in the water only. This no or less effects of blood and rice gruel could have resulted due to washing out of blood and rice gruel with flowing water because mustard oil cake could not hold blood and rice gruel for an adequate time that can be useful in absorbing protein from blood and carbohydrate from rice gruel. Hasan et al.(8) have found significantly higher yield of 
tubifex in blood wetted media where uncrushed soybean meal was used as media ingredient including mustard oil cake. Their finding is different from our observation because they used ungrounded soybean meal which have acted as shell to hold the blood and rice gruel which in turned were used by the worms for their faster and better growth and yield.

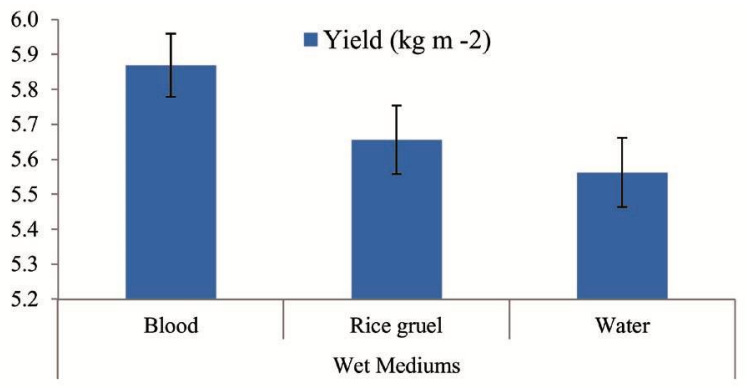

Fig. 1 Yield of tubifex worms $\left(\mathrm{kg} \mathrm{m}^{-2}\right)$ harvested from the experiment conducted between 12 May to 21 July 2017. Media ingredient used was only mustard oil cake at $50 \mathrm{mg} \mathrm{cm}^{-2}$ wetted in blood, rice gruel and subsurface clean water. Values (mean \pm 1 SEM) with no letters are not significantly different (ANOVA, HSD; $\mathrm{p} \varangle$.05).

\section{Experiment 2:}

Yield ( $\left.\mathrm{kg} \mathrm{m}^{-2}\right)$ of tubifex worms on media ingredients 75 and $100\left(\mathrm{mg} \mathrm{cm}^{-2}\right)$ across two worms innoculums 75 and $100\left(\mathrm{mg} \mathrm{cm}^{-2}\right)$ : The overall effects of applying two doses of culture media ingredients at the rate of 75 and $100\left(\mathrm{mg} \mathrm{cm}^{-2}\right)$ across two levels of worms inoculums 75 and $100\left(\mathrm{mg} \mathrm{cm}^{-2}\right)$ yielded nearly $6.65 \mathrm{~kg} \mathrm{~m}^{-2}$ worms in the treatment given $75 \mathrm{mg} \mathrm{cm}^{-2}$ mustard oil cake which is significantly higher ( $\left.\mathrm{p} \varangle 0.05\right)$ than the yield of 100 $\mathrm{mg} \mathrm{cm}^{-2}\left(6.31 \mathrm{~kg} \mathrm{~m}^{-2}\right)$ treatment (Fig. 2).

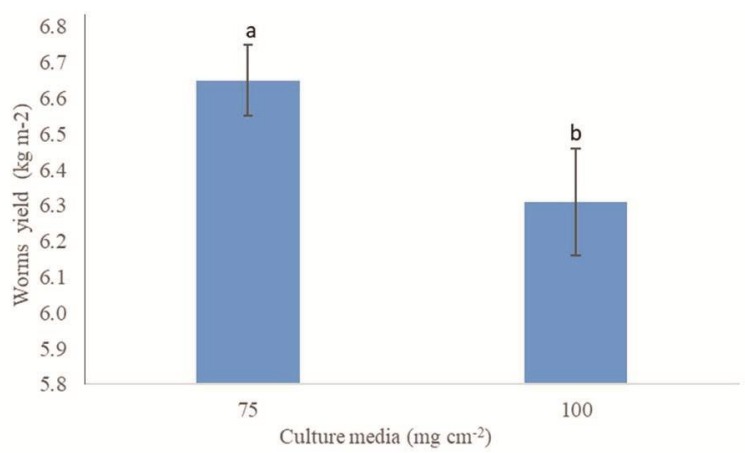

Fig. 2 Overall effects of culture media ingredient mustard oil cake $\left(\mathrm{mg} \mathrm{cm}^{-2}\right)$ on the yield of worms $\left(\mathrm{kg} \mathrm{m}^{-2}\right)$. Scale bars (mean $\pm 1 \mathrm{SEM}$ ) with different superscripts are significantly different (ANOVA, HSD; $\mathrm{p}<0.05$ ). 
Significantly higher yield in the treatment given $75 \mathrm{mg} \mathrm{cm}^{-2}$ mustard oil cake across two levels of worms inoculums 75 and $100\left(\mathrm{mg} \mathrm{cm}^{-2}\right)$ might have resulted because of easy initial adaptation to the mud where mustard oil cake was applied one day later. Because the inoculation day and later period before applying the culture media ingredient mustard oil cake, the worms got enough time to settle into the mud of the frontal part of the body and leaving the posterior part above the mud to respire. In addition, evenly distribution of worms over the mud confirmed the maximum utilization of the media( ${ }^{(8)}$.

\section{Experiment 2.1:}

Overall effects of inoculums 75 and $100\left(\mathrm{mg} \mathrm{cm}^{-2}\right)$ on the yield of tubifex worms $\left(\mathrm{kg} \mathrm{m}^{-2}\right)$ across two media ingredient 75 and $100\left(\mathrm{mg} \mathrm{cm}^{-2}\right)$ treatments: The overall effects of applying two doses of worms inocula at the rate of 75 and $100\left(\mathrm{mg} \mathrm{cm}^{-2}\right)$ across two levels of culture media ingredients 75 and $100\left(\mathrm{mg} \mathrm{cm}^{-2}\right)$ yielded nearly $6.68 \mathrm{~kg} \mathrm{~m}^{-2}$ worms in the treatment given $100 \mathrm{mg} \mathrm{cm}^{-2}$ of worms inocula which is significantly higher than the yield of $75 \mathrm{mg} \mathrm{cm}^{-2}\left(6.28 \mathrm{~kg} \mathrm{~m}^{-2}\right)$ treatment (Fig. 3).

Tubifex worm's inoculum at $100 \mathrm{mg} \mathrm{cm}^{-2}$ have yielded significantly higher $(\mathrm{p}<0.05)$ yield than did the $75 \mathrm{mg} \mathrm{cm}^{-2}$ is expected ${ }^{(8)}$. Because the higher the inoculum size the greater the absorption of the nutrients which might enhance maturation and reproduction of the worms to grow and propagate quickly.

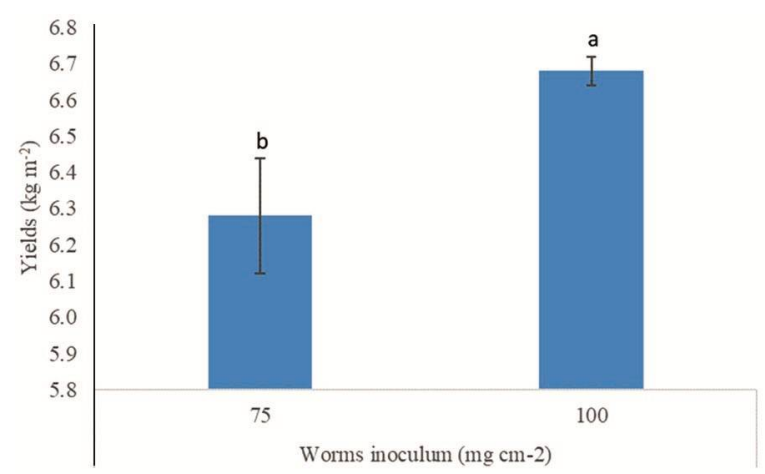

Fig. 3. Overall effects of tubifex worms' inoculum $\left(\mathrm{mg} \mathrm{cm}^{-2}\right)$ on the yield of worms $\left(\mathrm{kg} \mathrm{m}^{-2}\right)$. Bars (mean $\pm 1 \mathrm{SEM}$ ) with different superscripts denote significant difference (ANOVA, HSD; $\mathrm{p} \varangle 0.05)$.

\section{Experiment 2.2:}

Effects of two inoculums 75 and $100\left(\mathrm{mg} \mathrm{cm}^{-2}\right)$ in $75\left(\mathrm{mg} \mathrm{cm}^{-2}\right)$ mustard oil cake treatment: In $75 \mathrm{mg} \mathrm{cm}^{-2}$ media treatment, $100 \mathrm{mg} \mathrm{cm}^{-2}$ inoculum treatment had the significantly ( $\mathrm{p}<$ $0.05)$ higher yield of worms $\left(6.72 \mathrm{~kg} \mathrm{~m}^{-2}\right)$ than did the $75 \mathrm{mg} \mathrm{cm}^{-2}\left(6.58 \mathrm{~kg} \mathrm{~m}^{-2}\right)$ treatment (Fig. 4). 


\section{Experiment 2.3:}

Effects of 75 and $100 \mathrm{mg} \mathrm{cm}^{-2}$ inoculums in $100 \mathrm{mg} \mathrm{cm}^{-2}$ mustard oil cake treatment: Similarly, in $100 \mathrm{mg} \mathrm{cm}^{-2}$ media treatment, $100 \mathrm{mg} \mathrm{cm}^{-2}$ inoculum treatment resulted in the significantly higher $(\mathrm{p}<0.05)$ yield of worms $6.64 \mathrm{~kg} \mathrm{~m}^{-2}$ than in the $75 \mathrm{mg} \mathrm{cm}-2(5.98$ $\mathrm{kg} \mathrm{m}^{-2}$; Fig. 5).

Hossain et al.(15) and Mollah et al.(1) have found highest yield of worms 5.18 and 5.03 $\mathrm{kg} \mathrm{m}^{-2}$, respectively, in which $250 \mathrm{mg} \mathrm{cm}^{-2}$ water wetted media was used in a 10-days interval. In addition, $3.53 \mathrm{~kg} \mathrm{~m}^{-2}$ yield of tubifex worms were reported when the media ingredients applied at the rate of $200 \mathrm{mg} \mathrm{cm}^{-2}$ per 7-days break ${ }^{(16)}$.

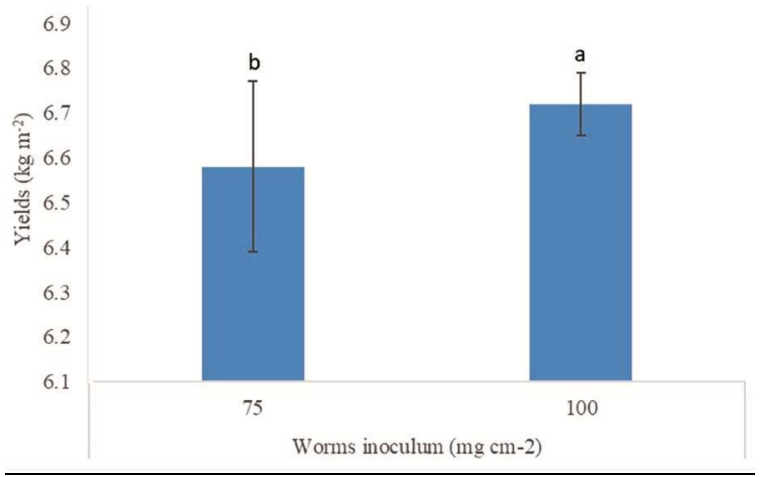

Fig. 4. Effects of tubifex inoculum 75 and $100\left(\mathrm{mg} \mathrm{cm}^{-2}\right)$ in the treatment $75\left(\mathrm{mg} \mathrm{cm}^{-2}\right)$ on culture media ingredient on the yield of worms $\left(\mathrm{kg} \mathrm{m}^{-2}\right)$. Bars (mean $\pm 1 \mathrm{SEM}$ ) with different superscripts indicate significant difference (ANOVA, HSD; $\mathrm{p}<0.05$ ).

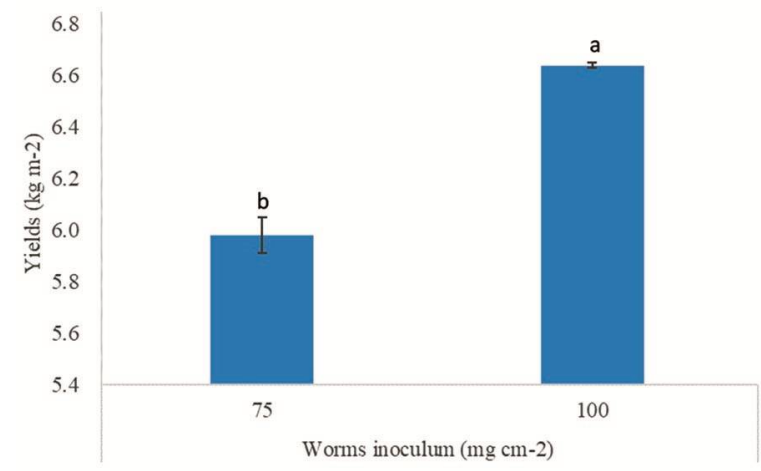

Fig. 4. Effects of tubifex culture media ingredients $100\left(\mathrm{mg} \mathrm{cm}^{-2}\right)$ on the yield of worms $\left(\mathrm{kg} \mathrm{m}^{-2}\right)$. Bars (mean $\pm 1 \mathrm{SEM}$ ) with different superscripts indicate significant difference (ANOVA, HSD; $\mathrm{p} \varangle 0.05)$.

Furthermore, Hasan et al.(8) observed $5.84 \mathrm{~kg} \mathrm{~m}^{-2}$ worms yield when water wetted media application was of $250 \mathrm{mg} \mathrm{cm}^{-2}$ over a 7-days intermission. All of these experiments used two or more media ingredients including cow dung and sand as the 
substrate whereas the current study suggests that only mustard oil cake $\left(75 \mathrm{mg} \mathrm{cm}^{-2}\right)$ with $100 \mathrm{mg} \mathrm{cm}^{-2}$ worm's inoculum might be the suitable combination of water media ingredient and inoculum size for significantly higher production of tubifex.

\section{Conclusions}

Wet media does not affect tubifex worms yield significantly. Mustard oil cake can be used to culture worms to avoid jelly like moulds. Use of MOC at $75 \mathrm{mg} \mathrm{cm}^{-2}$ can be used

at the starting dose of MOC. Renewal may also be done at $75 \mathrm{mg} \mathrm{cm}^{-2}$ with 7 days interval. The combination of $75 \mathrm{mg} \mathrm{cm}^{-2}$ media (MOC) and $100 \mathrm{mg} \mathrm{cm}^{-2}$ inoculums (worms) is the best combination of pilot scale culture of fish live food tubifex worms.

\section{Acknowledgements}

Mahmud Hasan wishes to thank Asiatic Society of Bangladesh for their financial support (2017) to conduct this study. We are grateful to Alhaj Firoz Khan, Proprietor, Maa Fatema Fish Hatchery, Jashore, Bangladesh for providing the water supply to undertake this study.

\section{References}

1. Mollah MFA, K Mosharaf and Mariom 2012. Selection of suitable media and intervals of media inoculation for culturing tubificid worms. J. Bangladesh Agric. Univ. 10: 325- 330.

2. Brinkhurst RO and CR Kennedy 1965. Studies on the biology of Tubificidae (Annelida, Oligochaeta) in a polluted stream. J. Anim. Ecol. 34:429-443.

3. Barnes RD 1966. Invertebrate Zoology. W.B. Saunders Company, Philadelphia, London. Pp 362.

4. Mariom L, N Sharmin, and MFA Mollah 2016. Identification of genera of tubificid worms in Bangladesh through morphological study. Asian J. Med. Biol. Res. 2: 27-32. https://doi.org/10.3329/ajmbr.v2i1.27565.

5. Haque MI, AR Alam, N Akter, MA Siddique, M Sultana, MA Hossain and M Hasan 2020. Molecular characterization of 'tubifex worms' based on 16S rRNA and cytochrome c oxidase subunit I. Aqua. Repor.116:100292. https://doi.org/10.1016/.aqrep.2020.100292.

6. Giere $\mathrm{O}$ and $\mathrm{O}$ Pfannkuche 1982. Biology and ecology of marine oligochaete, a review.In: Oceanography and Marine Biology (ed. M. Barnes), pp. 173-308. Aberdeen University Press.

7. FRSS 2019. Fisheries Statistical Yearbook of Bangladesh. Fisheries Resources Survey System (FRSS), Department of Fisheries, Bangladesh. 36: 40.

8. Hasan M, MI Haque, N Akter, MS Rahman and AS Eti 2019. Effects of wetting media cattle blood, rice gruel and water on the yield and amino acid composition of tubificid worms. J. Asiat. Soc. Bangladesh, Sci. 45(2): 229-39.

9. Alam MS and MFA Mollah 1988. Formulation of an artificial dry feed for primary nursing of catfish (Clarias batrachus L) larvae. Bangladesh J. Fish. 11(1): 71-75. 
10. Mollah MFA, MSA Mamun, MN Sarowar and A Roy 2009. Effects of stocking density on the growth and breeding performance of broodfish and larval growth and survival of shol, Channa striatus (Bloch). J. Bangladesh Agril. Univ. 7(2): 425-430.

11. Mandal RN, S Kar, PP Chakrabarti, DN Chattopadhyay, BN Paul, S Adhikari, J Maity and BR Pillai 2018. Production of tubifex - a new dimension of aquaculture in feeding juvenile fish. Aquacult. Asia. 22: 20-24.

12. Balandrán-Quintana RR, JN Mercado-Ruiz and AM Mendoza-Wilson 2015. Wheat bran proteins: a review of their uses and potential. Food Rev. Intl. 31(3): 279-293.

13. Hasan M. 2003. Growth and feed utilization of tilapia (Oreochromis niloticus Linn.) fed with different protein sources with and without vitamin. Dhaka Univ. J. Biol. Sci. 12: 105-113.

14. Sarker AK, D Saha. H Begum, A Zaman and MM Rahman 2015. Comparison of cake compositions, pepsin digestibility and amino acids concentration of proteins isolated from blackmustard and yellow mustard cakes. AMB Express. 5: 22. https://doi.10.1186/s13568015-0110-y.

15. Hossain A., MS Rahman and M Hasan 2011. Optimum harvest for sustainable yield of fish live food tubificid worms. Dhaka Univ. J. Biol. Sci. 20: 57-63.

16. Hossain A, MFA Mollah and M Hasan 2012. Ratio optimization of media ingredients for mass culture of Tubificid worms (Oligochaeta, Tubificidae) in Bangladesh. Asian Fish. Sci. 25: 357-368.

17. Mariom and MFA Mollah 2012. Development of a suitable culture medium for the production of tubificid worms. Asian Fish. Sci. 25: 40-51.

18. Begum M, P Noor, KN Ahmed, N Sultana, MR Hasan and LC Mohanta 2014. Development of a culture techniques for Tubificid worm, under laboratory conditions. Bangladesh J. Zool. 42(1): 117-122.

19. Mandal RN, S Kar, DN Chattopadhyay, J Maity, BN Paul, PP Chakrabarti and P Jayasankar 2016. Tubifex production using agro-industrial wastes and raw cattle dung. J. Appl. Aqua. 28: 70-75.

(Received on 11 August, 2021; accepted on 25 November, 2021) 